\title{
ETHICS
}

\section{Children of Jehovah's Witnesses and adolescent Jehovah's Witnesses: what are their rights?}

\section{S Woolley}

Arch Dis Child 2005;90:715-719. doi: 10.1136/adc.2004.067843

The Jehovah's Witnesses Society (JW), a fundamentalist Christian sect, is best known to laypersons and healthcare professionals for its refusal of blood products, even when such a refusal may result in death. Since the introduction of the blood ban in 1945, JW parents have fought for their rights to refuse blood on behalf of their children, based on religious beliefs and their right to raise children as they see fit. Adolescent JWs have also sought to refuse blood products based on their beliefs, regardless of the views of their parents.

Correspondence to: Dr S Woolley, Bristol Royal Infirmary/Bristol Royal Hospital for Children, Upper Maudlin Street, Bristol, UK; woolley_s@ hotmail.com

Accepted 18 January 2005
$\mathrm{T}$ raditionally, except in the emergency situation, parental consent is required in order to perform medical procedures on children, including adolescents. Courts throughout the western world recognise that parents have rights but additionally recognise that these rights are not absolute and exist only to promote the welfare of children. Worldwide, JWs have challenged this view. In addition to parental challenges adolescent JWs have been fighting their own battle to be recognised as mature enough to make their own decisions regarding blood products. Unfortunately, where the courts have been consistent regarding young children, they have been equally inconsistent where adolescent JWs are concerned.

The legal inconsistencies mean that confusion still exists amongst the medical profession about their legal liability if they transfuse children of JW parents or adolescents of the JW faith. This article examines cases from the United States, Canada, the United Kingdom, and Australia, and clarifies any confusion that may exist regarding the necessary transfusion of the children of JWs and the refusal of blood products by adolescent JWs.

The Jehovah's Witness Society is a fundamenfollowers believe the Bible is the true word of God. ${ }^{1}$ The most rapidly growing religious organisation in the western world, ${ }^{2}$ there are approximately 5500000 committed, baptised members, ${ }^{3}$ 125000 of whom reside in the United Kingdom. ${ }^{4}$ To many people, JWs are best known for their absolute refusal of blood products, even when death may result. This refusal is based on the belief that transfused blood is a nutrient, ${ }^{5}$ with three Biblical passages allegedly forbidding transfusion: Genesis 9:4, Leviticus 17:11-14, and Acts 15:20,29. The punishment for accepting blood products is loss of eternal life and on earth, a type of excommunication. talist Christian Sect, based in New York, whose

\section{YOUNG CHILDREN OF JEHOVAH'S WITNESSES}

Traditionally, where young children are concerned, the power to give or withhold consent to medical treatment on their behalf lies with those with parental responsibility. Legally, except in an emergency, parental consent is necessary to perform any medical procedure on a child. Two commonly used arguments when parents refuse treatment are parental rights to raise children as they see fit $^{6}$ and religious freedom. ${ }^{7} \mathrm{JW}$ parents have expressed both these arguments when defending their right to refuse blood on behalf of their children.

Courts throughout the western world recognise parental rights, but these rights are not absolute. ${ }^{8}$ Parental rights to raise children are qualified by a duty to ensure their health, safety, and wellbeing. ${ }^{9}$ Parents cannot make decisions that may permanently harm or otherwise impair their healthy development. ${ }^{10}{ }^{11}$

If treatment refusal results in a child suffering, parents may be criminally liable. ' However, prosecution rarely occurs. Instead, the courts are asked to exercise their power under the doctrine of parens patriae which allows state interference to protect a child's welfare. Used frequently when parental religious beliefs preclude specific treatments, Prince $v$ Massachusetts ${ }^{12}$ set out the reigning legal principle:

\footnotetext{
"Parents may be free to become martyrs themselves. But it does not follow that they are free, in identical circumstances, to make martyrs of their children..." ${ }^{\prime 13}$
}

This principle applies whether or not the child is in imminent danger, as parents are always required to make decisions in the child's best interests. When parental refusal is based on religious beliefs, the court can justify compulsory medical treatment ${ }^{14}$ based on the avoidance of physical harm. ${ }^{15}$

\section{United States}

In the USA, the Free Exercise Clause of the First Amendment ${ }^{16}$ is relied on by parents when defending their right to refuse blood on their children's behalf. This defence is rarely successful: ${ }^{17}$ the freedom to believe is absolute; the right to act on that belief is not. ${ }^{18}$ In American courts there is no doubt: the child's welfare is paramount.

The Watchtower Society issued the blood product ban in 1945 and the first case concerning a JW child appeared before the US court in 
1951. ${ }^{19}$ The parents of a child with erythroblastosis fetalis refused to authorise a blood transfusion, adamant in their beliefs that God's law prohibited blood. ${ }^{20}$ An initial court petition granted custody to the probation service, who gave consent for a transfusion. In the public's interest, the Illinois Supreme Court granted a hearing of the parents' appeal, and although recognising that "freedom of religion and the right of parents to the care and training of their children are to be accorded the highest possible respect in our basic scheme", ${ }^{21}$ the court upheld its view in Prince. ${ }^{12}$

In 1952, the matter was clarified further. ${ }^{22}$ Justifying compulsory blood transfusion based on four points-(1) minimal danger, (2) treatment efficacy, (3) lack of alternative treatments, and (4) based on religious beliefs-adults cannot choose to be responsible for the death of their children and, declaring no interest in Biblical interpretation, the court stated clearly that, if parental religious beliefs placed a child's life in danger then the state could intervene to protect the child. ${ }^{23}$

Theoretically this case should have ended any discussion regarding the parental ability to refuse blood on their children's behalf, but cases continued to appear before the courts. Some cases reiterated old decisions, ${ }^{24}$ others brought new decisions, increasing the state's ability to protect children by extending the right of protection to the unborn child $^{25}$ and introducing the concept of neglect into JW cases. ${ }^{26}$ Declaring a child neglected under state law $^{27}$ allowed transfusion despite parental objection.

The next important case extended court authorised transfusion to the possible, rather than the definite, need for blood. ${ }^{28}$ Although the child did not require blood imminently, the court contended that the New York State Children's Bill of Rights made it clear that parents no longer had the right to deny children required medical care and that "under no circumstances, with or without due process, with or without religious sanction, may they deprive him of his life" ${ }^{\prime 29}$ Unusually, the judge commented on JWs' beliefs ${ }^{29}$ and clarified that when a child's right to live and parental religious beliefs collide, the child's welfare is paramount.

The first JW case, ${ }^{30}$ concerning parental treatment refusal, to reach the US Supreme Court, challenged two statutes ${ }^{31}$ commonly used to declare children wards of court in order to administer blood, and sought a court order to prevent Washington physicians administering blood to JW patients. The Supreme Court was clear in its upholding of the decision in Prince ${ }^{12}$ explaining, "the right to practice religion freely does not include liberty to expose...the child...to ill health or death". ${ }^{32}$

The majority (with the exception of one ${ }^{33}$ ) of subsequent cases $^{34-41}$ have maintained the trend, reiterating the views of earlier cases and emphasising three main points:

- The child's interests and those of the state outweigh parental rights to refuse medical treatment ${ }^{42}$

- Parental rights do not give parents life and death authority over their children ${ }^{12} 42$

- Parents do not have an absolute right to refuse medical treatment for their children based on their religious beliefs. ${ }^{12} 43$

\section{United Kingdom}

Well established in British law, is the fundamental principle that every person's body is inviolate. ${ }^{44}$ Traditionally, under British law, while regarding the child's welfare as paramount, ${ }^{45}$ courts respect parental wishes concerning children's medical treatment. ${ }^{46}$ Parents have the right and the duty to give proxy consent, where required, for a minor. ${ }^{47}$ Some argue that when parents refuse treatment, any procedure is an assault on the child. ${ }^{48}$ However, as parental rights and duties are not absolute, ${ }^{49}$ existing only for the child's best interests, ${ }^{50}$ the court, ultimately, has overriding control. ${ }^{45}$

Established in $1875,{ }^{51}$ the prevailing law in British jurisprudence regarding parental treatment refusal on religious grounds remains unchallenged: parents who fail to obtain medical treatment for their children, are subject to criminal liability even if their refusal is religiously based. In contrast to the USA, there are only three JW cases in the UK contesting the well established legal opinion on parental treatment refusal. In all three cases $\left(\operatorname{Re} O{ }^{52} \operatorname{Re} S,{ }^{53} \operatorname{Re} R^{54}\right)$, permission for transfusion was granted, confirming the judicial opinion of the US courts: the child's interests are paramount. The court did stress, however, that although the child's welfare is paramount, consideration would be given to parental beliefs, particularly when the situation was not imminently life threatening.

\section{Australia}

Australian courts adopt a similar view: the child's welfare is paramount. Every Australian jurisdiction has legislation permitting certain medical treatments, including blood transfusions, ${ }^{55}$ without parental consent. ${ }^{56}$ Unfortunately, inconsistencies in the wording of the legislation, ${ }^{57}$ makes interpretation difficult. All four cases appearing before the New South Wales Supreme Court arose because of the inconsistent wording. The first case ${ }^{58}$ clarified the requirements of the NSW Child (Care and Protection) Act, that decisions regarding medical treatment of minors must be in the child's best interests, that decisions about treatment urgency rest with the medical profession, and that parens patriae authority may override a parental decision.

The second case $\mathrm{e}^{59}$ sought to clarify whether a transfusion necessary to alleviate "an appreciable risk of serious damage to the child's health" equated to "necessary to prevent serious damage to the child's health" under the NSW Child (Care and Protection) Act. Unfortunately, the court failed to consider in any depth the Act's provisions, leaving it open to further challenges. In the third case, ${ }^{60}$ brought before the courts by a doctor concerned about the detrimental effect his decision would have on the doctor-patient relationship, the doctor was criticised for wasting the court's time. The court, however, recognised that parental awareness of the Act's provisions was important, particularly when despite religious objections, the parents are happy to obey the law.

Most recently, the court reiterated the necessity for courts to override parental objections if the child is at risk. ${ }^{61}$ While respecting parental wishes regarding blood products as much as possible, the judge concluded that because the child's welfare is paramount, doctors can administer blood when necessary.

\section{ADOLESCENT JEHOVAH'S WITNESSES}

The rights of adolescents to refuse medical treatment vary throughout the world and this judicial inconsistency creates confusion among healthcare workers. In England and Wales, mature minors may consent to, but not refuse, treatment, with the courts using the "best interests" test to override the opinions of adolescents. In Scotland, although the Age of Legal Capacity (Scotland) Act does not specifically refer to treatment refusal, the inference is that a child deemed competent could refuse, as well as consent to, treatment. In North America, the situation for mature minors is state/ province dependent.

\section{United Kingdom}

The legal position with regard to mature minors remains ambiguous. In 1969, the Family Law Reform $\mathrm{Act}^{62}$ set the age of consent for medical treatment at 16 but did not specifically deal with parental-child conflict. The implication, however, is 
that a child's consent to a procedure overrides parental opinion. If refusing treatment, however, parents (and indeed the Court) in England and Wales may override the child. In Scotland, this is less likely to happen.

In a child under 16, four main issues arise: (1) the child's capacity to consent to treatment; (2) parental authority and its limitations; (3) whose view prevails when parents and children clash; and (4) the extent of the courts' powers over adolescents. Gillick $v$ West Norfolk ${ }^{63}$ considered the first three issues, with the majority of the House of Lords holding that, if a child under 16 could demonstrate sufficient understanding and intelligence to understand fully the treatment proposed they could give their consent to treatment. ${ }^{63}$ If they failed this competency test, parental consent is required. Unfortunately, treatment refusal was not considered. However, this case did specify the limitations of parental rights: "parental rights are derived from parental duty...exist only so long as they are needed for the protection of...the child" ${ }^{64}$

The logical inference from Gillick $^{63}$ is that competent children are competent to both accept and refuse treatment; yet subsequent decisions ${ }^{65}{ }^{66}$ suggest that a child's refusal may be overridden by a proxy's consent to that treatment and that the child's refusal, while important, may not be conclusive. ${ }^{66}$

$\operatorname{Re} R^{67}$ sought to clarify a minor's right to refuse treatment. However, by emphasising that, unlike adults who are presumed competent, minors must prove their competence, ${ }^{68}$ and by suggesting that as both parents and children were keyholders to the door of consent, ${ }^{69}$ parental consent would be sufficient in circumstances of disagreement, the court undermined the Children Act 1989, which sought to enable mature minors to make medical decisions. ${ }^{70}$ Additionally, Lord Donaldson made it clear that the court, in addition to parents, could override a minor's decision. ${ }^{71}$ Essentially this case disempowered minors with regards treatment refusal.

Re $W^{66}$ confirmed the courts ability to override parents, children, and doctors when performing its protective functions, but imposed limits on the power to overrule, with the judge stating that this power should only be exercised if "the child's welfare is threatened by a serious and imminent risk that the child will suffer grave and irreversible mental or physical harm" ${ }^{72}$ All three cases concerning adolescent JWs refusing blood ${ }^{73-75}$ reinforce the decisions made in $R e R^{67}$ and Re $W{ }^{66}$

The initial test of the "Gillick competence" concept came in Re E. ${ }^{74}$ With parental support, a JW aged 15\%/4 refused the blood transfusions associated with conventional leukaemia treatment. Court approval was sought to treat him. His parents argued that his wishes should be respected, as he was nearly 16, at which point his consent would be required.$^{76}$ In a carefully reasoned judgment, the judge overrode both the child and his parents, deeming the child not "Gillick competent" ${ }^{\prime \prime 7}$

Ward J recognised not only the distinction between knowing the fact of death and fully appreciating the death process, but also the absence of freedom in a teenager ${ }^{78}$ "conditioned by the very powerful expressions of faith to which all members of the creed adhere". ${ }^{74}$ Confirming wardship and authorising treatment for the welfare of the child, ${ }^{79}$ he concluded that although parents may martyr themselves, the "court should be very slow to allow an infant to martyr himself". ${ }^{74}$

$\operatorname{Re} S^{73}$ presented the court with a further opportunity to clarify the question of minors and treatment refusal. Influenced by her mother, $\mathrm{S}$ had been attending regular JW meetings and decided that she no longer wanted the blood transfusions necessary to treat her thalassaemia major. Court intervention was requested and after careful consideration the judge declared S not "Gillick competent". ${ }^{73}$ Despite an outward portrayal of confidence, ${ }^{73} \mathrm{~S}$ lacked the maturity of many girls of her age, had led a sheltered life, and showed a lack of understanding about her disease, the mode of death, ${ }^{80}$ and the seriousness of her decision (believing in miracles and not understanding that transfusion refusal would certainly result in death). ${ }^{81}$ The court should therefore authorise treatment in her best interests.

In $\operatorname{Re} L^{75}$ the decision was much easier. The young JW had serious burns and it was impossible to explain to her the severity of her injuries or the unpleasant nature of her death ${ }^{75}$ which would occur without vital blood products. The court deemed her Gillick incompetent because, despite the sincerity of her religious beliefs, she was only 14 and had limited life experience.

Logically, the Gillick competence concept should ability to both consent to and refusal of treatment. Nevertheless, under English and Welsh law, minors have no absolute right to refuse medical treatment. ${ }^{82}$ In the cases described above, the courts concluded that although the minors showed some evidence of maturity and understanding, they lacked sufficient understanding and experience to refuse treatment offering a high probability of success at a relatively low risk. Where treatment refusal was religion based, there was concern about the child's freedom of choice in the context of a religious upbringing in addition to concerns about whether the child fully grasped the implications of treatment refusal. Thus, while a child's refusal should be considered, it is likely that the court will override the refusal in the child's best interests. ${ }^{83}$

\section{Canada}

Canadian cases involving adolescent JWs fall into two categories: those supporting the rights of adolescents to refuse medical treatment, and those refuting the suggestion that adolescents are mature enough to make life or death decisions.

Pre-1996, the majority of cases supported the concept of adolescent JWs making medical treatment decisions. In $1985,{ }^{84}$ the judge, believing that the emotional trauma of receiving unwanted blood products would have a negative effect on the child's treatment and having determined that her parents had arranged suitable treatment elsewhere, refused to declare the child neglected ${ }^{85}$ or sanction an unwanted transfusion. In 1993, the Newfoundland Family Court reached a similar decision, ${ }^{86}$ declaring that blood was not essential, ${ }^{87}$ that the child was a mature minor with a sincerely held belief, ${ }^{88}$ and that a holistic approach to treatment was important.

Although the New Brunswick Court of Appeal's ${ }^{89}$ decision supported adolescents in their decision making capacity, based on several important facts-(1) Canadian common law allows mature minors to consent to their own treatment; (2) Section 3 of the Medical Consent of Minors Act $^{90}$ is determinative if two medical practitioners declare the child mature; and (3) unlike the UK, the Medical Consent of Minors Act allows mature minors to refuse treatment-no other decisions since have supported this view.

While earlier Canadian cases supported the notion of adolescent autonomy, cases since $1996^{91-93}$ support the English view that adolescents lack the maturity to refuse life saving treatment. The Ontario Court ${ }^{91}$ recognised that forcing a child to accept blood products against her religious belief was indeed an infringement of her freedom of religion. However, in the court's opinion, legislation that existed to protect minors reasonably justified limiting a child's freedom of religion. All three cases, as in the UK, accept that the child's opinion should be considered, but reiterate the point that the court can override the decisions of both children and their parents. 


\section{United States}

Traditionally, US minors have no legal rights ${ }^{94}$ and remain under parental jurisdiction until they reach the age of majority. Over the past century, however, legislation has altered this, allowing minors to obtain treatment for specific conditions without parental consent ${ }^{95} 96$ and, in some states, make medical treatment decisions. ${ }^{97}$ Unfortunately, the inconsistency of legal decisions regarding adolescent JWs is clearly evident in the USA.

Although not recognised by the US Supreme Court, some states have a "mature minor" doctrine, which allows some minors to consent to medical treatment without parental consent. ${ }^{98}$ Courts in Pennsylvania ${ }^{33}$ and Illinois have legally recognised this doctrine, with the Illinois Supreme Court ${ }^{99}$ recognising that minors have a common law right to refuse medical treatment and determining that, although Supreme Court judgements were lacking, individual judges could determine "whether a minor is mature enough to make health care choices". ${ }^{99}$ Unfortunately for adolescent JWs, the court qualified this right, noting that it was not absolute and had to be balanced against state interests. ${ }^{100}$ Additionally, in circumstances of parental-child conflict, parental wishes might override the child's decision.

Other states recognise the existence of a "mature minors" doctrine but will not act on it. ${ }^{101}{ }^{102}$ Instead, they adopt the English court's approach declaring adolescent JWs immature and lacking in understanding of religious beliefs and the consequences of refusing treatment. ${ }^{103}$ The most recent case confuses the issue further as the Massachusetts Appeals court granted minors the right to determine their own medical treatment. ${ }^{104}$ Placing emphasis on the evaluation of a minor's maturity, the court directed judges to consider a minor's wishes and religious convictions and to receive the testimony of minors. ${ }^{105}$ Unfortunately, only three states ${ }^{106}$ use the mature minor exception to consent to or refuse specific medical treatment, and the majority of adolescents rely on parental decision-making.

\section{CONCLUSION}

With regard to religious based refusal of blood products by parents, courts in the western world are of the opinion that the child's welfare is paramount and blood can be given. Consideration should be given to parental views and treatment moderated where possible but if conflict occurs, the child's interests always come first.

Regarding adolescents, there is no worldwide consensus on the legal position of adolescents refusing blood transfusions, but recent cases suggest that the UK's approach is probably the most acceptable. While many children raised in JW communities may never experience the "outside world", the judiciary would be wrong not to give them that opportunity. Religion is a powerful persuading voice, but it is also an individual belief. A limited life experience cannot truly give one the opportunity to rationalise a belief that may eventually lead to death.

Competing interests: none declared

\section{REFERENCES AND NOTES}

1 Harrison BG. Visions of glory: a history and memory of Jehovah's Witnesses. New York: Simon and Schuster, 1978.

2 Stark R, lannaconne LR. Why the Jehovah's Witnesses grow so rapidly: a theoretical application. Journal of Contemporary Religion 1997; 12:133-57.

3 Ridley DT. Honoring Jehovah's Witnesses' advance directives in emergencies: a response to Drs. Migden and Braen. Acad Emerg Med 1998;5:824-35

4 Khadra $M$, et al. A criterion audit of women's awareness of blood transfusions in pregnancy. BMC Pregnancy and Childbirth 2002;2:7 (www.biomedcentral.com/1471-2393/2/7).

5 Anon. The Watchtower, 1 July 1951, page 415: "A patient in hospital may be fed through the mouth, through the nose or through the veins. When sugar solutions are given intravenously, it is called intravenous feeding. So the hospital's own terminology recognizes as feeding the process of putting nutrition into one's system via the veins. Hence the attendant administering the transfusion is feeding the patient blood through the veins, and the patient receiving it is eating through his veins."

6 Meyer v Nebraska 262 US 390 (1923), Wisconsin v Yoder 406 US 205 (1972), Stanley v Illinois 405 US 645 (1972), Santosky v Kramer 455 US 745 (1982), Planned Parenthood v Casey 505 US 833 (1992), Burge v City and County of San Francisco 262 P.2d 6 (Cal. 1953).

7 In re Seithfert 127 NE.2d 820 (NY 1955), In re Green 292 A.2d 387 (Pa. 1972), State v Lockhart 664 P.2d 1059 (Okl. Cr. 1983), In re Hudson 126 P.2d 765 (Wash. 1942), Bradley v State 79 So. 651 (Fla. 1920).

8 Parental rights not absolute: Newmark v Williams 588 A.2d 1108 (Del. 1991), Jacobson v Massachusetts 197 US 11 (1905), Hawaii v Standard Oil Co. 405 US 251 (1972); Rejection of the Free Exercise Clause: Prince v Massachusetts (1944) 321 US 158, Walker v Superior Court 763 P.2d 852 (1988), Commonwealth v Barnhardt 497 A.2d 616 (Pa. Super. 1985), Craig v State 220 Md. 590 (1959), People v Pierson 176 NY 201 (1903), State v Norman 808 P.2d 1159 (Wash. Ct. App. 1991), Funkhauser v State 763 P.2d 695 (1988), Commonwealth v Nickson 718 A.2d 311 (Pa. Super. Ct. 1998), In Re Custody of a Minor 379 NE.2d 1053 (Mass. 1978), Commonwealth $v$ Twitchell 617 NE.2d 609 (Mass. 1993).

9 CYPA 1933, s(1) and (2)(a) but liability here is not as a parent but as a person over 16 having the "custody, charge, or care" of a child under 16.

10 Dwyer JG. The Children we Abandon: Religious Exemption to Child Welfare and Education Laws as Denials of Equal Protection to Children of Religious Objectors. North Carolina L. Rev 1996;74:1321.

11 Queensland Law Reform Commission, Consent to medical treatment of young people: discussion paper 34-35 (1995) (internal citations omitted).

12 Prince $v$ Massachusetts (1944) 321 US 158.

13 lbid at 170

14 In re Eric B. 235 Cal. Rptr. 22, 24-27 (Cal. Ct. App. 1987) ruling that despite absence of actual harm, threat of harm if child was not periodically monitored for cancer was sufficient to permit juvenile court's jurisdiction to order monitoring.

15 In re McCauley, 565, N.E.2d 411 (Mass. 1991) (ruling that best interests of child, coupled with state's strong interest in securing a life-saving blood transfusion, outweighed parents' constitutional objections); State $v$. Perricone, 181 A.2d 751 (N.J. 1962), cert. denied, 371 U.S. 890 (1962) (holding court-ordered blood transfusion did not violate parents' constitutional rights of religion or parental autonomy when the child's life was in danger); Wallace v. Labrenze, 104 N.E.2d 769 (IIl. 1952), cert. denied, 344 U.S. 824 (1952) finding that when parents refuse medical treatment for their child, the lack of which will almost certainly cause death or, at best, lifelong mental impairment, the child is neglected and the court may order the necessary treatment without violating the parents' constitutional rights); Morrison v. State, 252 S.W.2d 97 (Mo. 1952) (holding that state has power to preserve a child's life and health when medical treatment is as necessary for the child's survival as is food); Commonwealth v. Cottam, 616 A.2d 988, 1000 (Pa. Super. Ct. 1992) (ruling that in criminal case against defendant parents over death of children due to neglect, validity and sincerity of religious beliefs of defendants and children are not relevant to issues presented at trial for failing in legal duty to provide for children, resulting in starvation death of son and severe malnutrition of daughter).

16 US Constitution amendment 1: "Congress shall make no law respecting an establishment of religion, or prohibiting the free exercise thereof..."

17 Lingle EA. Treating children by faith: colliding constitutional issues. J Legal Med 1996;17:301-6.

18 Reynolds v United States 98 US 145, 166 (1878), Employment Div. Dept of Human Resources v Smith, 494 US 872 (1990)

19 People ex rel. Wallace et al. v Labrenz et al., 104 N.E.2d 769 (IL 1952).

20 Ibid at 772: "We feel that we would be breaking God's commandment, also destroying the baby's life for future, not only this life, in case the baby should die and breaks the commandment, not only destroys our chances but also the baby's chances for future life. We feel it is more important than this life."

21 Ibid at 773.

22 Morrison v State 252 S.W.2d 97 (MO C. of A. 1952): Janet Morrison, a 12 day old child with erythroblastic leukaemia, required blood to live. Her JW parents refused based on interpretation of Leviticus 17:10-14 and Genesis 9:4-5.

23 Ibid at 101-2.

24 State v Perricone 181 A.2d 751 (NJ 1962)

25 Hoener v Bertinato 171 A.2d 140 (NJ Juv. \& Dom. Rel. C. 1961).

26 Santos v Goldstein 227 N.Y.S.2d 450 (NY 1962): "The parents, because of religious convictions, refused to give consent to a blood transfusion, which may have been required given the nature of the surgery."

27 "Neglected" within the meaning of section 2 (subd. [17], par. [g] of the New York City Domestic Relations Court Act). The court stressed that the parents were not negligent in any other way.

28 In re Clark 185 N.E.2d 128 (OH C. of Corn. Pl., Div. Of Dom. Rel. 1962): Kenneth Clark, a 3 year old boy with $40 \%$ burns, may have required a blood transfusion during his treatment. The hospital sought a court order declaring that blood may be administered if necessary because the child's JW parents would not consent to transfusion.

29 Ibid at 131

30 Jehovah's Witnesses v King County Hospital 278 F. Supp. 488 (W.D. Wash. 1967) aff'd 390 U.S. 598 (1968)

31 Wash. Rev. Code § 13.04.010(12), § 13.04 .095 (1961).

32 Jehovah's Witnesses v King County Hospital 278 F. Supp. At 504 (quoting Prince v Massachusetts, 321 U.S. 158, 166-67 (1944) (quoting People v Pierson 176 N.Y. 201, 68 N.E. 243)).

33 In re Green 448 Pa. 338, 292 A.2d 387 (PA Supreme Court, 1972).

34 In re Sampson 317 N.Y.S.2d 641 (NY Fain. C. 1970). 
35 Muhlenberg Hospital v Patterson 320 A.2d 518 (NJ Sup. C., Law D. 1974)

36 In Interest of lvey 318 So.2d 53 (FL D.C. of A., 1 Dist 1975).

37 In the Matter of Tara Cabrera, a Minor 552 A.2d 1114 (Pa. Super. 1989) 6 year old girl, parental objection to transfusion for sickle cell anaemia. Court confirmed that state interests overrode parents' religious objections. Limited therapy to one year.

38 In the Interest of JV, a Child 516 So.2d 1133

39 In the Matter of Baby Girl Newton, 1990 WL 54916 (Del.Ch.) (Unpublished opinion)-court appointed guardian because of risk of imminent serious physical harm.

40 In the Matter of Elisha McCauley 565 N.E.2d 411 (Mass. 1991).

41 Cooper $v$ Wiley 513 N.Y.S.2d 151 (A. D. 1 Dept. 1987).

42 Custody of a Minor 375 Mass. 733, 379 N.E.2d 1053 (1978).

43 Jacobson V Massachusetts 197 U.S. 11 (1905)

$44 \operatorname{Re} F$ (Mental Patient: Sterilisation) [1990] 2 AC 1, 72E as per Lord Goff.

$45 \operatorname{In} \operatorname{Re}$ B (A Minor)(Wardship: Medical Treatment) 1 WLR 1421 (1981).

$46 \operatorname{Re} Z$ (A Minor) (Identification: Restrictions on Publication) [1997] Fam 1, 32 as per Johnson J: "I would for my part accept without reservation that the decision of a devoted and responsible parent should be treated with respect. It should certainly not be disregarded or lightly set aside.".

47 Gillick v West Norfolk AHA [1986] 1 AC 12 at $184 G$ as per Lord Scarman.

$48 \operatorname{Re} R$ (A Minor)(Wardship: Consent to Treatment) [1992] Fam. 11 at 22 as per Lord Donaldson of Lymington MR.

49 "...the common law has never treated such rights as sovereign or beyond review and control". Gillick v West Norfolk AHA [1986] 1 AC 112 at 184A as per Lord Scarman.

$50 J_{V} C[1970]$ AC 668

51 The Queen v Robert Downes (1875-1876) LR 1 QBD 25 Crown Cases Reserved. This case reversed a previous decision made in The Queen v Wagstaffe 10 Cox. Crim. Cas. 530 (1868) where the jury returned a not guilty verdict on parents who had allowed their child to die from a treatable illness because they were members of the "Peculiar People" who did not believe in conventional medical therapy. This case was responsible for the "Poor Law Amendment" which mandated the administration of conventional medical therapy for children whose health was imperilled, irrespective of religious beliefs.

$52 \operatorname{Re} O$ (A Minor) (Medical Treatment) [1993] 1 FCR 925, [1993] 2 FLR 149.

$53 \operatorname{Re} S$ (A Minor) (Medical Treatment) [1993] 1 FLR 376.

54 Re R (A Minor) (Blood Transfusion) [1993] 2 FCR 544

55 Skene L. You, your doctor and the law. Melbourne: Oxford University Press, 1990:172.

56 Western Australia: Human Tissue and Transplant Act 1982 section 21. Queensland: Transplantation and Anatomy Act 1979 section 20; Tasmania Human Tissue Act 1985 section 21; Victoria: Human Tissue Act 1982 section 24; Australian Capital Territory: Transplantation and Anatomy Act 1978 section 23; Northern Territory: Emergency Medical Operations Act 1973 sections 2 and 3; South Australia: Consent to Medical and Dental Procedures Act 1985 sections 6(2), (3), (5), (6); New South Wales: Children (Care and Protection) Act 1987 section 20A.

57 Western Australia, Queensland, Tasmania, Victoria, ACT: "... if child is in danger of death without treatment.."; Northern Territory: "... if it is not reasonably practical to delay until consent is obtained and the patient is in danger of dying or of suffering a serious permanent disability"; South Australia: "... if the emergency procedure is required to meet an imminent risk to the life or health of the child"; New South Wales: 'if the treatment is necessary to save the life of the child or prevent serious damage to his/her health".

58 Birkett v Director General of Family and Community Services (Unreported decision of Supreme Court of New South Wales, 3 Feb. 1994, No. 3161 of 1991).

59 Dalton v Skuthorpe (unreported decision of Supreme Court of New South Wales, 17 Nov. 1992, No. 5094 of 1992.

60 Marchant $v$ Finney (unreported decision of Supreme Court of New South Wales, 31 July 1992, No. 3599 of 1992).

61 Director General, Department of Community Services Plaintiff and BB Defendants [1999] NSWSC 1169 (19 November 1999).

62 Family Law Reform Act 1969 Section 1 (1).

63 Gillick v West Norfolk and Wisbech AHA [1985] 3 All ER 402

$64 \mathrm{lbid}$ at 420

65 Re R (A Minor) (Wardship: Consent to Medical Treatment) [1992] Fam. 11.

$66 \operatorname{Re}$ W (A Minor) (Medical Treatment: Court's Jurisdiction) [1993] Fam. 64

$67 \operatorname{Re} R$ (A minor) (Wardship: Medical Treatment) [1991] 4 All ER 177.

$68 \mathrm{lbid}$ at $187 \mathrm{E}$ by demonstrating "a full understanding and appreciation of the consequences, both of the treatment in terms of intended and possible side effects, and equally important, the anticipated consequences of a failure to treat".

$69 \mathrm{Ibid}$ at 246F: "There can be concurrent powers to consent. If more than one body or person has a power of consent, only a failure to, or refusal of, consent by all having that power will create a veto"

70 Family Law, All ER Annual Review, 176, 178-179 (1991).

71 Fennell P, et al. Medical Law, All ER Annual Review 230 at 235 (1991).

72 Supra note 66 at 94.

73 Re S (A Minor) (Wardship: Medical Treatment) [1994] 2 FLR 1065.

$74 \mathrm{Re}$ E (A Minor) (Wardship: Medical Treatment) [1993] 1 FLR 386.

$75 \operatorname{Re}$ L (Medical Treatment: Gillick Competence) [1999] 2 FCR 524, [1998] 2 FLR 810.

76 Under the Family Law Reform Act 1969.

77 Supra note 74 "He is a boy of sufficient intelligence to be able to take decisions about his own well-being, but...there is a range of decisions of which some are outside his ability fully to grasp their implications. Impressed as I am by his obvious intelligence, by his calm discussion of the implications, by his assertion that he would refuse well knowing that he may die as a result, in my judgement [he] does not have a full understanding of the whole implication of what the refusal of that treatment involves".

78 Supra note 74 at 394E: "I have to take account of the fact that teenagers offen express views with vehemence and conviction-all the vehemence and conviction of youth... .remember the convictions we have loudly proclaimed which we now find somewhat embarrassing".

79 Supra note 74 at 394F: "...I find it essential for his well-being to protect him from himself and his parents..."

80 Ibid: "There were a lot of things that concerned me, the patness of her replies, some of her phrases. She and her mother were using exactly similar phraseology. [S] was not able to explain her thoughts except that, "it was said in the Bible'. She had no understanding of the manner in which she might die."

81 Ibid at 615: "She does not understand the full implications of what will happen. It does not seem to me that her capacity is commensurate with the gravity of the decision which she has made. It seems to me that an understanding that she will die is not enough. For her decision to carry weight she should have a greater understanding of the manner of the death and pain and the distress."

82 Harper RS. Medical treatment and the law. The protection of adults and minors in the family division. Bristol: Family Law, Jordan Publishing Limited, 1999:88.

83 BRB $\vee$ JB [1968] 2 All ER 1023 at 1025D Lord Denning MR: "...the views of the child should be taken into consideration; but the child's views are never decisive".

84 Re LDK; Children's Aid Society of Metropolitan Toronto v K and K (1985) 48 RFL (2d) 164, 23 CRR 337

85 Defined by the Child Welfare Act RSO 1980 c. 66, s. 19 sub-clause (ix): "a child where the person in whose charge the child is neglects or refuses to provide or obtain proper medical, surgical or other recognized remedial care or treatment necessary for the child's health or well-being, or refuses to permit such care or treatment to be supplied to the child when it is recommended by a legally qualified medical practitioner, or otherwise fails to protect the child adequately".

$86 \operatorname{Re} Y$.(A.) (1993) 111 NFld. \& PEIR 91, 348 APR 91

$87 \mathrm{Ibid}$ as per Wells $\mathrm{J}$ : "I am not satisfied that in this particular case that the use of blood products as a follow up to the chemotherapy is considered essential by the qualified medical practitioner from whom I have heard, and in whom I have every confidence."

88 Ibid as per Wells J: "I am satisfied that he believes, with all his heart, that to take blood would be wrong, and that to be forced to take blood in the circumstances about which we are speaking, would be an invasion of his body, an invasion of his privacy, and an invasion of his whole being, to the extent that it would impact severely on his strength and ability to cope with the dreadful ordeal that he has to undergo, whatever the outcome."

89 Walker (Litigation Guardian of) v Region 2 Hospital Corp. (1994) 4 RFL (4th) 321, 116 DLR (4th) 477, 150 NBR (2d) 366, 385 APR 366.

90 The Medical Consent of Minors Act was enacted in 1976. New Brunswick is the only province that has enacted the act.

$91 H(T) v$ Children's Aid Society of Metropolitan Toronto (1996) 138 DLR (4th) 144 (sub nom. Children's Aid Society of Metropolitan Toronto v TH) 9 OTC 274,37 CRR (2d) 270

92 U (C.).)(Next Friend of) v Alberta (Director of Child Welfare), 2000 ABQB 626, [2001] 3 WWR 575, 273 AR 106, 87 Alta LR (3d) 144, 3 WWR 575, [2000] AJ No. 1067

93 Alberta (Director of Child Welfare) v H (B), 2002 ABPC 39, [2002] 11 WWR 752, 6 Alta LR (4th) 34, 31 RFL (5th) 16.

94 Hawkins SD. Protecting the Rights and Interests of Competent Minors in Litigated Medical Treatment Disputes. Fordham Law Review 1996;64:2075-6.

95 Planned Parenthood v Danforth 428 US 52 (1976).

96 Felsman JP. Eliminating parental consent and notification for adolescent HIV testing: a legitimate statutory response to the AIDS epidemic. $J L \&$ Pol'y 1996:5:339.

97 Batterman N. Under age: a minors right to consent to health care. Touro $L$ Rev 1994; $10: 637$

98 Ark. Stat. Ann. § 20-9-602(7)(Michie 1991); Nev. Rev. Stat. § 129.030(2) (1991).

99 In re EG 549 N.E.2d 322 at 328 (III. 1989).

100 Namely: preserving life, protecting third parties, preventing suicide and protecting the medical profession.

101 In re Long Island Jewish Med. Ctr., 557 N.Y. S. 2d 239, 243 (Sup. Ct. 1990)

102 Novak v Cob-County-Kennestone Hospital 849F Supp 1559 (NDGA 1994).

103 Ibid Child was unaware of the relevant Biblical passages, stated several times that a court-ordered transfusion absolved him of responsibility, and classed himself as a child.

104 In re Rena 705 N.E. 2d 1155 (Mass. 1999).

105 Ibid at 1157 (stating "(1) the patient's expressed preferences, if any; (2) the patient's religious convictions, if any; (3) the impact on the patient's family; (4) the probability of adverse side effects from the treatment; (5) the prognosis without treatment; and (6) the present and future incompetency of the patient in making that decision").

106 In re EG 549 N.E.2d 322 at 328 (III. 1989), Belcher v Charleston Area Med. Ctr., 422 S.E.2d 827 (W. Va. 1992) and W. VA. CODE \& 16-30C-6 (1998); Cardwell v Bechtol 724 S.W.2d 739 (Tenn. 1987). 